\title{
Complex (Street talk Recorded)
}

The man's words came thick

As epileptic foam

think about blackout

you think about blackman

think about black lists

you think about blackman

think about black lies

you think about blackman

think of blackmarkets

you think about blackman

this black body no good. . .

His self-image caught me as

Doorhandle a Fulaman's gown

Rending my heart

when those people looked at us

peeеeеeеeеeеeеeengh

and called us

monkeys

you think it was for nothing?

was it for nothing?

$i$ tell you

we are like that

we cannot part with our

black palms

we cannot part with our black ways... .!

I stood under the barrage

More stunned than stone

Thinking

No wonder

With such a mind

No wonder, brother

You hang behind like buttocks

To sit on. 